\title{
EU Employment Law and the European Social Model: The Past, the Present and the Future
}

\section{Catherine Barnard*}

\begin{abstract}
If the critics are right, the European Union's (EU's) social model is dead and that is the end of it. Those on the right may well be dancing on its grave; those more sympathetic might mourn its passing. My view is more sanguine. I shall argue that the European social model is certainly facing unprecedented challenges. However, I will suggest that these challenges, caused in part by the EU's response to the crisis but more generally resulting from a growing hostility towards the European Union project as a whole, are not terminal and that there is - and should be-a continued role for the European social model. The article therefore considers what is meant by the European social model (ESM) and why the ESM is important. It then examines why the ESM, and its employment dimension in particular, is facing such difficulties before recognizing that, in fact, the EU's history demonstrates that the ESM has, in fact, a long-standing ability to regenerate and resurrect itself in different guises. Given this regenerative capacity, the article will conclude by considering the form EU social policy might take going forward.
\end{abstract}

The European social model has already gone when we see the youth unemployment rates prevailing in some countries. These [labour market] reforms are necessary to increase employment, especially youth employment, and therefore expenditure and consumption.

Q\&A with Mario Draghi, Wall Street Journal, 22 February $2012^{1}$

* Trinity College, Cambridge. Email: csb24@cam.ac.uk. Thanks to Sjoerd Feenstra, Bob Hepple, Steve Peers and Fotis Vergis for helpful comments and discussions. Particular thanks are due to the participants at the seminar hosted at the University of Granada in January 2014, the audience at UCL attending the CLP lecture in May 2014 for their helpful observations and questions, to the participants at the seminar series on a European Social Union hosted by Frank Vandenbroucke, University of Leuven, and to Virginia Mantouvalou and an anonymous referee.

1 <http://blogs.wsj.com/eurocrisis/2012/02/23/qa-ecb-president-mario-draghi/ > accessed 20 July 2014. 


\section{Introduction}

The phrase 'European social model' has been used to mean all things to all institutions. For the Commission, values lie at its core. For example, in its White Paper on Social Policy, ${ }^{2}$ the Commission said that the values underpinning the European Social Model (ESM) include:

...democracy and individual rights, free collective bargaining, the market economy, equality of opportunity for all and social welfare and solidarity. These values... are held together by the conviction that economic and social progress must go hand in hand. Competitiveness and solidarity have both been taken into account in building a successful Europe for the future.

For the heads of state, meeting at the Nice European Council in December 2000, the European Social Model was primarily about European Union (EU) legislation in the field of employment law: ${ }^{3}$

The European social model has developed over the last forty years through a substantial [Union] acquis... It now includes essential texts in numerous areas: free movement of workers, gender equality at work, health and safety of workers, working and employment conditions and, more recently, the fight against all forms of discrimination.

However, the Heads of States did recognize a broader vision of the European social model which included the agreements between the Social Partners in the law-making process, the Luxembourg European Employment Strategy (EES), and the open method of co-ordination (OMC) on the subject of social exclusion, and greater co-operation in the field of social protection. ${ }^{4}$

These institutional observations indicate that there is no single EU concept of the ESM. Rather, the ESM is a flexible idea which embraces an eclectic range of policies from employment law, as narrowly defined, ${ }^{5}$ to the creation of the welfare state, including education, healthcare and social security. ${ }^{6}$ The ESM also involves shared values, in particular those listed in Article 3 of the Treaty on European Union (TEU)

$2 \operatorname{COM}(94)$ 333, para 3. See further Nick Adnett and Stephen Hardy, The European Social Model: Modernisation or Evolution (Edward Elgar 2005).

3 Para 12.

4 Para 11.

5 Wolfgang Streeck, 'From Market-Making to State Building? Reflection on the Political Economy of European Social Policy' in Stephen Leibfried and Paul Pierson (eds), European Social Policy: Between Fragmentation and Integration (The Brookings Institution 1995) 397.

6 See further Grainne de Búrca, Towards European Welfare' in Grainne de Búrca (ed), EU Law and the Welfare State: In Search of Solidarity (OUP 2005) 2-3. 
(including social justice, equality, and solidarity) and high standards. ${ }^{7}$ It is delivered in part through EU legislative initiatives, but also by the Member States and by the social partners at national and sub-national level. ${ }^{8}$ As Giddens succinctly notes, 'It has been aptly said that the ESM is not wholly European, not wholly social and not a model.'

Despite the lack of clarity as to what precisely is included under the rubric of the ESM, it is at least implicit in the EU institutions' observations that the social dimension is an integral part of the European Union project. According to the European Trade Union Confederation (ETUC),${ }^{10}$ it is intended 'to serve the welfare of all, in accordance with the tradition of social progress rooted in the history of Europe and confirmed in the Treaties'. And serving the 'welfare of all' does not just mean improving the economic status of individuals but also their social situation by providing them with a ladder up when times are good and a safety net to catch them when times are tough. That safety net includes preventing individuals from being mistreated at work, and providing them with protection when they are sick, poor, or old. Such protection is fundamental to a civilized society. Generally, it has been provided at the Member State level.

In this article, I will argue that an EU, with a weakened legitimacy, should not set about dismantling this protection through an unthinking, mechanical application of the four freedoms. The troika, too, in its work with the 'bail-out' states needs to be aware of the impact that its conditionality requirements are having on the national social systems. However, I wish to go further and argue for a continued, positive role for the EU in the building of a distinctive social model. I shall concentrate on the EU's employment (law) dimension. ${ }^{11}$ As the quote from the Nice European Council indicates, this is what has traditionally been seen as the core of the ESM, and it is my area of expertise.

7 See eg Commission Communication, 'Employment and Social Policies: A Framework for Investing in Quality' (COM(2001) 313, 5).

8 Wolfgang Streeck, 'Neo-voluntarism: A New European Social Policy Regime' (1995) 1 ELJ 31.

9 Anthony Giddens, Turbulent and Mighty Continent: What Future for Europe? (Polity 2014) 88.

$10<$ http://www.etuc.org/a/5175> accessed 20 July 2014.

11 Fritz Scharpf draws a distinction between negative and positive integration in his book Governing in Europe: Effective and Democratic (OUP 1999) ch 3. For criticism, see Olivier De Schutter, 'The Democratic Experimentalist Approach to Governance: Protecting Social Rights in the European Union' in Olivier De Schutter and Jacques Lenoble (eds), Reflexive Governance: Redefining the Public Interest in a Pluralistic World (Hart Publishing 2010) 115. 
Any discussion about the future of EU employment law must be located in a consideration of the past, and an understanding of why some, including Mario Draghi (quoted at the beginning of this article), consider that the ESM is dead. While I think that the reports of the death of the ESM are exaggerated, I would certainly agree that the ESM is facing some sort of existential crisis. ${ }^{12}$ In the next section ('The Crisis of the European Social Model'), I shall identify three specific crises facing the ESM: a crisis of legitimacy, a crisis of purpose, and a crisis of regulation. They are inter-related and reflect a deeper crisis of confidence in the EU. I will, however, argue in the section entitled 'An alternative narrative' that this perception of crisis masks a reality of survival for the ESM, and it is against this backcloth of survival that it is possible to fashion an ESM for the future. This is considered in the section called 'What is the future of EU Social Policy?'. The final part of the article draws some conclusions.

\section{The Crisis of the European Social Model}

Of the three crises facing the EU-legitimacy, purpose, and regulationthe latter two feed into the former. However, for the purposes of exposition, I will treat the crises as distinct. I will begin by considering the crisis of legitimacy.

\section{Crisis of Legitimacy}

\section{In policy-making}

Failure of delivery. The Treaties are replete with expressions of highminded ideals. Pluralism, non-discrimination, tolerance, justice, solidarity, and equality between women and men are expressly identified as values of the EU in Article 2 TEU. These values must be read in the light of the objectives of the EU listed in Article 3(3) TEU: The Union shall 'work for the sustainable development of Europe based on balanced economic growth and price stability'. It is to have a 'highly competitive social market economy', a phrase which, according to the Constitutional

\footnotetext{
12 On the use of the term crisis, see Janet Roitman, Anti-Crisis (Duke University Press 2014); Jean Clam, 'What is a Crisis?' in Poul Kjaer, Gunther Teubner and Alberto Febbrajo (eds), The Financial Crisis in Constitutional Perspective: The Dark Side of Functional Differentiation (Hart Publishing 2011) 189.
} 
Convention, ${ }^{13}$ was intended to underline the link between the economic and social development of the EU, and the efforts made to ensure greater coherence between economic and social policies. In particular, the EU's social market economy should aim at full employment and social progress. New mainstreaming provisions have also been introduced, in particular Article 9 Treaty on the Functioning of the EU (TFEU) requiring the Union to take into account the promotion of 'a high level of employment, ${ }^{14}$ the guarantee of adequate social protection, [and] the fight against social exclusion.... More generally, Article 3(1) TEU provides that 'The Union's aim is to promote peace, its values and the well-being of its peoples'.

Yet, to the citizens of Greece and Portugal, and to a lesser extent Spain and Ireland, these commitments — whatever their legal status ${ }^{15}$ - ring hollow. ${ }^{16}$ At best they are rhetorical flourishes which might have some meaning in the good times. At worst, they are pious statements of good intentions which mask the reality of their daily lives. ${ }^{17}$ The dramatic reforms to the Greek and Portuguese labour law systems, introduced as a form of conditionality to the bail-out programmes - and thus required by external 'troika' actors ${ }^{18}$ - are well known. ${ }^{19}$ Not only does the EU stand accused of hypocrisy but also of acting unlawfully, as the ETUC argued in its submissions to the European Parliament: ${ }^{20}$

Fundamental principles and key objectives of the European Treaty are there to be respected at all times. The fact that programmes are elaborated under

13 Working Group XI on Social Europe (CONV 516/1/03 REV 1, para 17). See further Loïc Azoulai, 'The Court of Justice and the Social Market Economy: The Emergence of an Ideal and the Conditions for its Realization' (2008) 45 Comm Market L R 1335, 1337.

${ }_{14}$ See also Art 147(2) TFEU.

15 Cf Case 126/86 Zaera v Institut Nacional de la Seguridad Social [1987] ECR 3697, para 11 .

${ }_{16}$ For example, in Greece, cuts have reduced public wages by 30 points since 2010 and Portugal and Spain by 5 points, and poverty in Greece has risen to a historically high level, exceeding 35\% of the population in 2013: ILO Social Protection report 2014-2015, 113 and $137<$ http://www.ilo.org/wcmsp5/groups/public/—dgreports/—dcomm/docu ments/publication/wcms_245201.pdf $>$ accessed 20 July 2014.

17 See eg Philomila Tsoukala, 'Narratives of the European Crisis and the Future of (Social) Europe' (2013) 48 Texas Int LJ 241.

18 Floris de Witte, 'EU Law, Politics and the Social Question' (2013) 14 ELJ 581, 589-90.

19 Aristea Koukiadaki and Lefteris Kretsos, 'Opening Pandora's Box: The Sovereign Debt Crisis and Labour Market Regulation in Greece' (2012) 41 ILJ 276. For reaction, see eg 'Court Cases Threaten Greek Overhaul' International New York Times (13 June 2014) 1; Hermes Augusto Costa, 'From Europe as a Model to Europe as Austerity: The Impact of the Crisis on Portuguese Trade Unions' (2012) 18 ELJ 397.

$20<$ http://www.etuc.org/IMG/pdf/THE_FUNCTIONING_OF_THE_TROIKA_ finaledit2afterveronika.pdf $>$ accessed 20 July 2014. 
market and time pressure does not change this.... Indeed, disregarding, or even sacrificing, these social principles has led to one-sided, erroneous, and hence counterproductive, economic policies.... Moreover, there are also severe consequences for the project of European integration. If the social principles laid down in the Treaty are simply treated as a piece of paper, whereas unfettered markets and business interests are enforced in all possible ways, European integration becomes severely unbalanced and the confidence of workers and citizens in the project of European integration is undermined.

Priority of the economic over the social. Despite the commitment to a 'social market economy', social policy has always been seen as the poor relation to the EU's economic dimension. Article 148(2) TFEU supports this view: the EU's Employment Guidelines must respect the Broad Economic Policy Guidelines (BEPG), but not vice versa. In fact, the need for the national welfare systems, including labour law, to adapt to the economic imperatives of the single currency, had always been programmed into the Economic and Monetary Union (EMU) project. ${ }^{21}$ However, the apparent boom of the early 2000s disguised this imperative. Not only did the crisis accelerate the process of labour market reform, particularly in the bail-out countries, but also made it significantly more visible. But in the absence of any clear narrative of why these reforms were necessary, many workers felt they were being asked to pay the price for an economic crisis which began in the financial sector. They therefore saw the EU as the cause of their countries' troubles, not their saviour.

Furthermore, the European semester programme, the Commission's yearly cycle of policy coordination, now the epicentre of EU activity in the economic and the social field, is seen by many as continuing to drive forward a neo-liberal, deregulatory agenda. ${ }^{22}$ While I think this is too simplistic a characterization of the programme, ${ }^{23}$ it is certainly clear that the European semester is a complex, multi-layered, multi-institutional process which encourages, inter alia, significant reform to labour law systems in some countries. However, there is almost no public engagement in the process. For example, in Spain major changes have been made

21 Christophe Degryse, Maria Jepsen and Philippe Pochet, 'The Euro Crisis and its Impact on National and European Social Policies' (2013) ETUI Working Paper, 19; Philippe Pochet and Christophe Degryse, 'Monetary Union and the Stakes for Democracy and Social Policy' (2013) 19 Transfer 103, 107-8; Amy Verdun, 'An "asymmetrical" Economic and Monetary Union in the EU: Perceptions of Monetary Authorities and Social Partners' (1996) 20 J Eur Integr 59, 65.

22 This is considered further at $\mathrm{n} 71$ below.

23 Catherine Barnard, 'A European Nudge and a Domestic Think: Getting States to Reform their Labour Laws' (2014) Maastricht J Eur \& Comp L (forthcoming). 
to employment legislation, in particular the reforms of 2012. These changes have been precipitated in part by the European semester programme. Yet the Spanish parliament has not been involved in the discussions over the European semester; engagement has been only with civil servants and advisers. Those who are potentially interested, for example national trade unions, find it difficult to participate in this almost closed process. Even those who are immediately interested are often not consulted, due to the short time scales involved. Thus, 'Europe' is seen as dictating major reforms which are unwelcome, at least among trade unions.

In the judicial sphere. Thus, in terms of policy-making, the legitimacy crisis has both a substantive and a procedural dimension. At judicial level, the concerns are mainly substantive: in the (in)famous 2007 cases of Viking and Laval, ${ }^{24}$ the economic interests of migrant companies were seen to prevail over the social interests of (some groups of) workers. The Court did recognize in these cases that the right to take collective action, including the right to strike, was a fundamental right, and that the social interests of trade unions to call their members out on strike had to be balanced against the economic interests of the employers. However, the Court's actual approach, based on the standard internal market case law (namely the Säger ${ }^{25}$ market access approach, the main analytical tool used at the time), ${ }^{26}$ in fact favoured employers. The Court easily found that the collective action constituted a restriction on free movement and so breached Articles 49 and 56 TFEU. This forced the defendant trade unions not only to show that the strike action was justified (on a limited range of grounds) but was also proportionate. This resulted in the paradox that the more successful the strike action, the less likely it would be proportionate.

For the trade union movement, especially in the Northern European states, these decisions came as a body blow: a Court, which had traditionally been sympathetic to social claims, at least in the equality field, ${ }^{27}$ prioritized

\footnotetext{
${ }^{24}$ Case C-438/05 International Transport Workers' Federation and Finnish Seamen's Union v Viking Line ABP and OÜ Viking Line Eesti [2007] ECR I-10779 and Case 341/05 Laval un Partneri Ltd $v$ Svenska Byggnadsarbetareforbundet, Svenska Byggnadsarbetareförbundets avdelning 1, Byggettan and Svenska Elektrikerförbundet [2007] ECR I-11767.

25 Case C-76/90 Säger [1991] ECR I-4221 [12].

26 Alicia Hinarejos, 'Laval and Viking: the Right to Collective Action Versus Fundamental Freedoms' (2008) 8 Hum Rights LR 714.

27 See eg Case C-13/94 P v S and Cornwall County Council [1996] ECR I-2143 (dismissal on the ground of sex change is sex discriminatory); Case C-177/88 Dekker v Stichting Vormungscentrum voor Jong Volwassenen [1990] ECR I-3941 (discrimination on the grounds of pregnancy is per se directly discriminatory); Case C-303/06 Coleman
} 
employers' economic concerns over workers' collective interests when it came to the crunch. ${ }^{28}$ Although a certain softening towards the position of the social interests may be detected in some subsequent decisions, ${ }^{29}$ the damage had been done. The decisions fanned the perception that the EU did not care about social issues, especially collective ones. ${ }^{30}$

The Viking and Laval litigation also brought into sharp focus the structural problem facing the EU: its 'social deficit'. ${ }^{31}$ This takes two related forms. First, as a consequence of the initial decoupling of economic policy and social policy (with economic policy being delivered at EU level and with the benefit of the full force of primacy of EU law while social policy was left to the national level), social policy always remained vulnerable to challenge by the four freedoms and competition provisions of the TFEU. This problem was exacerbated when the Court started to apply the Säger market access approach with full force to non-discriminatory provisions of national social law. ${ }^{32}$

Second, while national social policy risks being dismantled in the face of negative integration, the expanded, but still limited, competence of the EU in the social field, together with limited political will and ambition, has not led to the recreation of social policy at EU level. The debacle over the Monti II proposal ${ }^{33}$ demonstrated this very clearly. ${ }^{34}$ Intended to help address some of the many criticisms levelled at the Viking and Laval decisions, the proposal could not be based on Article 153 TFEU, due

$v$ Attridge Law [2008] ECR I-5603 (associated discrimination on the grounds of disability is unlawful).

${ }_{28}$ There has been a certain backlash against this view: see Dorota Leczykiewicz, 'Conceptualising Conflict between the Economic and the Social in EU law after Viking and Laval, Oxford Legal Research Paper Series 27/2014. My point focuses mainly on the Court's approach to the right to take collective action.

29 Case C-271/08 Commission v Germany (occupational pensions) [2010] ECR I-7091.

30 See further Hans Micklitz 'Judicial Activism of the European Court of Justice and the Development of the European Social Model in Anti-discrimination and Consumer law' in Ulla Neergaard and others (eds), The Role of Courts in Developing a European Social Model: Theoretical and Methodological Perspectives (DJOF 2010).

31 Most famously, see Fritz Scharpf, 'The European Social Model: Coping with the Challenges of Diversity' (2002) 40 JCMS 645. cf Dragana Damjanovic, 'The EU Market Rules as Social Market Rules: Why the EU can be a Social Market Economy' (2013) 40 CMLR 1685.

32 Catherine Barnard, 'Restricting Restrictions: Lessons for the EU from the US?' (2009) 68 Cambridge LJ 575.

33 European Commission, 'Proposal for a Regulation on the Exercise of the Right to Take Collective Action Within the Context of the Freedom of Establishment and the Freedom to Provide Services' COM (2012) 130 final.

34 The adoptive parents, 'The Life of a Death Foretold: the Proposal for a Monti II Regulation' in Mark Freedland and Jeremias Prassl (eds), EU Law in the Member States: Viking, Laval and Beyond (Hart Publishing forthcoming). 
to the express exclusion in Article 153(5) TFEU of competence for the EU to legislate in the field of, inter alia, strike action. So the residual legal basis, Article 352 TFEU, was used, and this sets the bar high ('If action by the Union should prove necessary,...'). It also requires unanimous voting. In their objections to the Monti II proposal, articulated in their 'yellow cards', ${ }^{35}$ various states argued that there was no need for the EU to act at all. ${ }^{36}$

While the Monti II proposal was controversial in all quarters, ${ }^{37}$ its demise sent a clear signal that the prospects for adopting future social policy, at least under Article 352 TFEU, were all but dead. ${ }^{38}$ It therefore provided a concrete example of the fears expressed by Vandebroucke and Vanhercke that: ${ }^{39}$

the process of European integration has led to a loss of regulatory capacity, which must be restored, either at the European level or at the national level. This is not just worrying because of the need to regulate per se, but also because it may impact negatively upon the capacity to innovate social policies.

We shall return to the question of a crisis in regulation below.

What about the Charter of Fundamental Rights, and the Articles in the Solidarity Title in particular? Hailed by some as the great hope for social policy and as a significant countervailing force to the economic imperatives of the Treaty, it has, in fact, proved something of a damp squib. First, it seems the Articles in the 'Solidarity' Title may in fact be principles and not rights ${ }^{40}$ and so, according to Article 52(5) CFREU, require

35 See eg Federico Fabbrini and Katarzyna Granat, "Yellow Card, but no Foul”: the Role of the National Parliaments under the Subsidiarity Protocol and the Commission Proposal for an EU Regulation on the Right to Strike' (2013) 50 CMLR 115; Marco Goldoni, 'The Early Warning System and the Monti II Regulation: The Case for a Political Interpretation' (2014) 10 Eur Const LR 90.

36 See eg European Scrutiny Committee, 'Reasoned Opinion of the House of Commons Concerning a Draft Regulation on the Exercise of the Right to Take Collective Action Within the Context of the Freedom of Establishment and the Freedom to Provide Services' (UKHC 2012-13).

37 cf the adoptive parents (n 34 ).

38 The EU has successfully adopted the Enforcement Directive but under the single market legal basis, Articles 53(1) and 62 TFEU.

39 Frank Vandenbroucke and Bart Vanhercke, European Social Union: Ten Tough Nuts to Crack (Friends of Europe 2014) 52.

40 If this is the case, then the risk of the UK and Poland invoking Art 1(2) of Protocol 30 is reduced. See also Case C-396/13 Sähköalojen ammattiliitto ry v Elektrobudowa Spót ka Akcyjna, pending. 
implementation by the EU institutions, ${ }^{41}$ which, as the Monti II saga suggests, may now be easier said than done. Secondly, a number of social disputes arise in horizontal contexts (employee v private sector employer). While $A M S^{42}$ indicated that there was still a possibility that some of the provisions of the Charter could be applied horizontally, ${ }^{43}$ particularly Article 21 on non-discrimination, this was not the case with Article 27 on information and consultation and possibly the other provisions in the Solidarity Title. Thirdly, even where the Charter may be relevant, for example in challenging troika-mandated changes to national labour law systems, the Court has so far refused to hear such claims. ${ }^{44}$

In conclusion, the combined effect of the structural disequilibrium in the EU between the economic and social interests, together with the CJEU's unwillingness to do other than go with the Treaty's (economic) flow, as prescribed in 1957, have raised important questions as to the EU's legitimacy. This crisis of legitimacy is also reflected in the questions about the EU's purpose and its (in)ability to regulate.

\section{Crisis of Purpose}

The second crisis concerns the purpose of EU employment law: what should it actually be doing? For Kahn-Freund, the father of British labour law, the principal purpose of labour law was 'to regulate, to support and to restrain the power of management and the power of organised labour'. ${ }^{45}$

41 Article 52(5) CFREU continues that the principles shall be "judicially cognisable only in the interpretation of such acts and in the ruling on their legality'. See also the AG's Opinion in Case C-176/12 Association de médiation sociale v Union locale des syndicats CGT [2014] ECR I-000, ECLI:EU:C:2014:2 and the Court's decision in Case C-356/12 Wolfgang Glatzel v Freistaat Bayern [2014] ECR I-000, ECLI:EU:C:2014:350.

42 Case C-176/12 AMS [2014] ECR I-000, ECLI:EU:C:2014:2.

43 Para 42, 'it is settled case-law that the fundamental rights guaranteed in the legal order of the European Union are applicable in all situations governed by European Union law'.

44 Case C-434/11 Corpul Naţional al Poliţiştilor v Ministerul Administraţiei şi Internelor (MAI) and Others [2011] ECR I-196*; Case C-134/12 MAI v Corpul Naţional al Poliţiștilor - Biroul Executiv Central [2012] ECR I-000; ECLI:EU:C:2012:288; C-264/ 12 Sindicato Nacional dos Profissionais de Seguros e Afins [2014] ECR I-000; ECLI:EU:C:2014:2036. See also Giuseppe Bronzini, The European Social Model and the Constitutional Treaty of the European Union' in Christian Joerges, Bo Străht and Peter Wagner (eds), The Economy as a Polity: The Constitution of Contemporary Capitalism (UCL Press 2005) 192.

45 Paul Davies and Mark Freedland (eds), Kahn-Freund's Labour and the Law (3rd edn, Stevens 1977) 15. 
With the benefit of hindsight, the post-war years represented the heyday of labour law. ${ }^{46}$ Labour law was to be: ${ }^{47}$

[a] countervailing force to counteract the inequality of bargaining power which is inherent and must be inherent in the employment relationship. Most of what we call protective legislation-legislation on the employment of women, children and young persons, on safety in mines, factories, and offices, on payment of wages in cash, on guarantee payments, on race or sex discrimination, on unfair dismissal, and indeed most labour legislation altogether- must be seen in this context.

The ambition was not always so noble. As Deakin and Wilkinson show, 'the aim of stabilizing employment through collective bargaining and employment policy was to avoid a situation in which the costs of dealing with insecurity then fell entirely on the social security system'. ${ }^{48}$

However, the result was a flowering of social rights at national level. For this reason, it was originally thought unnecessary for the EU to act in the social sphere-and herein lies the origins of the 'social deficit' described above. ${ }^{49}$ That abstentionist position changed in the 1970s, and again in the late 1980s/early 1990s. In these periods, the EU produced a patchwork of labour law rules which broadly adopted a similar paternalist, 'floor of rights' approach to worker protection already found in the national systems. So, for example, the Social Charter Action Programme 1989 led to the adoption of the Working Time Directive, ${ }^{50}$ the Young Workers Directive, ${ }^{51}$ and the Pregnant Workers Directive, ${ }^{52}$ together with the wealth of health and safety directives. ${ }^{53}$

Yet, with the rise of neo-liberalism in the 1980s, and the move towards marketization, the paternalism of the post-war years was viewed very

46 Bob Hepple, 'Introduction' in Bob Hepple (ed), The Making of Labour Law in Europe (Hart Publishing 2010 reprint) 20 and Niklaas Bruun and Bob Hepple, 'Economic Policy and Labour Law' in Bob Hepple and Bruno Veneziani (eds), The Transformation of Labour Law in Europe (Hart Publishing 2010) 38.

47 Davies and Freedland (n 45) 18.

48 Simon Deakin and Frank Wilkinson, The Law of the Labour Market (OUP 2005) 343.

49 See n 31.

50 OJ $1993 \mathrm{~L} 307 / 18$.

51 OJ $1994 \mathrm{~L} 216 / 12$.

52 OJ 1992 L348/1.

53 Starting with the Framework Directive 89/391/EEC on health and safety (OJ [1989] L183/1). 
much as the product of the past. ${ }^{54}$ Labour laws and collective bargaining, instead of being seen as a necessary social stabilizer, were increasingly viewed as interfering with the free operation of the market. ${ }^{55}$ Neo-liberals considered that the market would ensure that workers enjoyed protection but through individual contracting, not collective agreements or legislation. In reality, what emerged was a reduced core of individuals who did still enjoy employment protection but an ever-expanding periphery of precarious workers who did not, ${ }^{56}$ in a labour market characterized by 'casualization, delayering, and non-linear-sequencing. 57

This profound shift in thinking raised questions about the role for labour law, and transnational labour law in particular, in regulating what was now termed the labour market. ${ }^{58}$ From the mid-1990s, the EU engaged in some reflection about the role and function of EU labour law. One response was to create a narrative that $(\mathrm{EU})$ employment law and growth were mutually reinforcing: social policy was an input into the productive process and not a burden on it. ${ }^{59}$ As the Commission said in its White Paper on Social Policy, 'the pursuit of high social standards should not be seen as a cost but also as a key element in the competitive formula ${ }^{60}$ This appeared to justify extensive EU level regulation. In fact, it paved the way for the advent of the neologism 'flexicurity ${ }^{361}$ which has

54 For a general overview, see Colin Crouch, The Strange Non-Death of Neo-liberalism (Polity Press 2011) 14.

55 See eg Colin Crouch, 'Entrenching Neo-liberalism: The Current Agenda of European Social Policy' in Nicola Countouris and Mark Freeland (eds), Resocialising Europe in a Time of Crisis (CUP 2013) 41.

${ }_{56}$ See specifically Guy Standing, The Precariat: The New Dangerous Class (Bloomsbury 2011).

57 Richard Sennet, The Culture of the New Capitalism (Yale University Press 2004) 46.

58 See Antoine Lyon-Caen, Remarks, EU Labour Law conference, European Commission, 21 October 2014 <http://ec.europa.eu/avservices/video/player.cfm?ref= I082772 > accessed 20 July 2014. For a general discussion on where should labour law be going, see Guy Davidov and Brian Langille (eds), The Idea of Labour Law (OUP 2011) and Katherine Stone and Harry Arthurs, Rethinking Workplace Regulation (Russell Sage 2013).

59 Simon Deakin and Frank Wilkinson, 'Rights vs Efficiency: the Economic Case for Transnational Labour Standards' (1994) 23 ILJ 289, 295-96; Erica Szyszczak, 'The New Paradigm for Social Policy: A Virtuous Circle' (2001) 38 CMLRev. 1125, 1134.

${ }^{60} \operatorname{COM}(94) 333$, introduction, para 5.

61 See generally Jeff Kenner, 'New Frontiers in EU Labour Law: From Flexicurity to Flex-security' in Samantha Currie and Michael Dougan (eds), Fifty Years of the Treaty of Rome (Hart Publishing 2009). 
driven much of the EU's policy agenda in recent years. ${ }^{62}$ The Commission has presented flexicurity in the following terms:

Flexibility internal to the enterprise not only promotes corporate productivity but also the quality of working life... Security for workers can also give benefits to the enterprise in the form of a more stable, versatile and motivated workforce. ${ }^{63}$

While the flexicurity agenda was highly contested-with many seeing flexibility for business triumphing over security for employees ${ }^{64}$ - flexicurity was the Commission's response to finding a 'third way' between the 'Anglo-Saxon' model of deregulation (low unemployment and fewer welfare benefits), and the European model of job protection (high unemployment, and generous welfare provision). The aim was to achieve competitiveness through creating highly productive, flexible workplaces, rather than combating unemployment through the creation of low-paid, low-productivity 'entry jobs'. 65

A further review of EU social policy in the mid-2000s, just before the crisis, saw whispers of another approach: capabilities, influenced by the work of the Nobel prize-winning economist Amartya Sen, who, together with Martha Nussbaum, ${ }^{66}$ argued that policies and institutions should be evaluated by reference to how far they enhance individual capabilities, ie the degrees of substantive freedom (eg life, health, bodily integrity, even employment) that enable individuals to achieve states of well-being ('functionings'). ${ }^{67}$ The EU's Opportunities, Access and Solidarity documents of 2007 and $2008^{68}$ were premised on the idea 'that whereas society cannot guarantee equal outcomes for its citizens, it must become

62 See especially, Commission's Communication, 'Towards Common Principles of Flexicurity: More and Better Jobs through Flexibility and Security' COM(2007) 359.

${ }_{63} \operatorname{COM}(98) 592,3$.

64 See eg Sally Ball, 'The European Employment Strategy: The Will but Not the Way?' (2001) 30 ILJ 353, 360.

65 Simon Deakin and Hannah Reed, 'The Contested Meaning of Labour Market Flexibility: Economic Theory and the Discourse of European Integration' in Jo Shaw (ed), Social Law and Policy in an Evolving European Union (Hart Publishing 2000).

66 Amartya Sen, Development as Freedom (OUP 1999); Martha Nussbaum, Creating Capabilities: the Human Development Approach (Harvard University Press 2011).

67 Simon Deakin and Ralf Rogowski, 'Reflexive Law, Capabilities and the Future of Social Europe' in Ralf Rogowski, Robert Salais and Noel Whiteside (eds), Transforming European Employment Policy: Labour Market Transitions and the Promotion of Capability (Edward Elgar 2011) 248; Simon Deakin and Frank Wilkinson, The Law of the Labour Market (OUP 2005) 342.

68 'Opportunities, Access and Solidarity: Towards a New Social Vision for 21st Century Europe' $\operatorname{COM}(2007) 726$ and 'Renewed Social Agenda: Opportunities, Access and Solidarity' $\operatorname{COM}(2008) 412$. 
much more resolute in fostering equal opportunities ... The central ambition is to achieve a wider distribution of 'life chances' to allow everyone in the EU to have access to the resources, services, conditions and capabilities in order to turn the theoretical equality of opportunities and active citizenship into a meaningful reality. ${ }^{69}$ In other words, EU law and policy as 'conversion factors' should be used to facilitate individuals' ability to maximize the talents they were born with, ie their 'endowments'. For labour lawyers, this theory offered an alternative justification for, for example, maternity protection legislation: they protected pregnant women from dismissal, thus preserving their capacity to engage in gainful—and rewarding_employment.

But these positive narratives for labour law were unceremoniously dumped when they came up against their first major challenge: the economic crisis and the financial collapse of Greece, Portugal, Ireland and, to all intents and purposes, Spain. ${ }^{70}$ The neo-liberal agenda asserted itself with full force. As a condition of the bail-out, the troika required stringent reforms to labour law: decentralization of collective bargaining, cuts to the minimum wage, and reform of unfair dismissal protection. For the European Central Bank (ECB), in its working paper on The European Labour Markets and the Crisis, these reforms were a necessity: ${ }^{71}$

More recently, the ongoing labour market reforms in countries such as Greece, Ireland, Portugal, Spain and Italy include some important measures to increase wage bargaining flexibility and reduce excessive employment protection, and constitute appropriate first steps to improve labour market and competitiveness performance in these countries and in the euro area as a whole.

Such 'internal devaluation' was seen as a major tool to turn round ailing economies (other tools such as currency devaluation were not available to Eurozone states). Yet decision-makers disregarded the fact that some highly successful economies which had weathered the crisis also had expensive welfare states to support and high levels of employment protection.

The deregulatory prescription was not confined to the bail-out countries. Part of the European semester process involves issuing

\footnotetext{
${ }^{69} \operatorname{COM}(2007) 726,6$.

70 Simon Deakin and Aristea Koukiadaki, 'The Sovereign Debt Crisis and the Evolution of Labour Law in Europe' in Countouris and Freedland (eds), Resocialising Europe in a Time of Crisis (CUP 2013) 177.

71 Structural Issues Report, 2012.
} 
country-specific recommendations (CSRs) to all the Member States on the economic and employment policies. As Degryse and others put it: ${ }^{72}$

it is impossible to deny that the CSRs do potentially open up a road to more radical reforms and to a form of social interventionism - inevitably deregulatory in its general thrust - in a manner that is more binding than was the case previously and with a stronger normative dimension aimed at increasing the sensitivity of social policies to market forces. ${ }^{73}$

And despite the well-documented failures of the market over recent years, the troika's response has largely been 'more market' to deal with the subsequent public debt. This has meant a push towards New Public Management (NPM) and more privatization of public services. And, as the experience in the UK has painfully shown, while the Transfer of Undertakings Directive 2001/23 provides some initial protection for the contracted out employees, in practice this protection lasts only for a limited time. ${ }^{74}$ Private sector employers tend to introduce other costsaving measures, notoriously the (ab)use of zero-hours contracts. As Sandel succinctly puts it, 'markets are not mere mechanisms; they embody certain values. And sometimes, market values crowd out nonmarket norms worth caring about'. ${ }^{75}$

\section{Crisis of Regulation}

So far we have looked at two crises: of legitimacy and of purpose. The third crisis relates to regulation, and in particular the EU's ability to regulate, a subject we have already touched upon with the discussion of the failure of Monti II. It is certainly true that, with the various reforms to the original Treaty of Rome, the EU's specific competences to act in the social field have been expanded (see in particular Article 153 TFEU), the ordinary legislative procedure has been extended and legislation can now be adopted not only via the traditional legislative route but also by the social partners. However,

See (n 21) 27.

73 See also Eftychia Achtsioglou and Michael Doherty, 'There Must Be Some Way Out of Here: The Crisis, Labour Rights and Member States in the Eye of the Storm' (2014) 20 ELJ 219, 220.

74 See Amy Ludlow, 'The Public Procurement Rules in Action: An Empirical Exploration of Social Impact and Ideology' (2014) 16 CYELS forthcoming.

5 Michael Sandel, What Money Can't Buy: The Moral Limits of Markets (Penguin 2012) 113. See also Emilios Christodoulidis, "The European Court of Justice and "Total Market" Thinking' (2013) 14 German LJ <http://www.germanlawjournal.com/index.php? pageID $=11 \&$ artID $=1589>$ accessed 28 July 2014 . 
the reality has been that the more competences the EU has been given, the harder it has been to adopt EU legislation. The reasons for this are well-known: an expanded and increasingly heterogeneous EU means that it is ever more difficult to regulate on any topic, let alone social policy, an area seen as so sensitive to so many national systems. It is no coincidence that the national parliaments chose to use the yellow card procedure for the first time ${ }^{76}$ in respect of a piece of social legislation, namely Monti II. ${ }^{77}$

Further, given the absence of a credible possibility that the EU will legislate on particular social matters, the employers' associations, notably BUSINESSEUROPE, no longer have the incentive to engage in European-level collective bargaining, with a view to reaching a collective agreement which can be extended to all workers. This, combined with the general weakness of the EU level social partners, ${ }^{78}$ the lack of capacity of the social partners in the Central and Eastern European states, and the controversy over the agreement on the health and safety of hairdressers, ${ }^{79}$ has meant that the collective route to legislation is currently in abeyance. More generally, Gumbrell-McCormick and Hyman point to the imbalance of influence between labour and capital. This is not just due to the imbalance of organizational resources, they say, but structure: 'employers and industrialists work with the grain of entrenched EU policy, while trade unions, if they are serious about "social Europe", seek a major change of course' ${ }^{80}$

There is a more fundamental problem: despite 40 years of EU social legislation, there is still a lack of a clear narrative as to why the EU should act in the social field. Is EU legislation intended to remove obstacles to free movement, to harmonise costs, to control the power of employers, or to legitimize the single market project? Each of these different rationales would envisage less-or more-EU legislation. This debate has never

\footnotetext{
$76<$ http://ec.europa.eu/dgs/secretariat_general/relations/relations_other/npo/letter_ to_nal_parl_en.htm > accessed 28 July 2014.

$7 \overline{C O M}(2012) 130$.

78 This is particularly so with the ETUC, but this in turn a reflection of the problems faced by national trade unions: Rebecca Gumbrell-McCormick and Richard Hyman, Trade Unions in Western Europe: Hard Times, Hard Choices (OUP 2013), especially chs 2 and 7.

$79<$ http://ec.europa.eu/social/main.jsp?langId=en\&catId=89\&newsId=1286\&further News=yes $>$ accessed 20 July 2014; 'High heels to be cut down to size under new EU proposals forcing hairdressers to wear non-slip flat shoes' Daily Mail (10 April 2012); 'EU's red tape trimming starts with hairdressers' The Times (3 October 2013). The Commission decided not to extend the agreement to all workers by a Directive: $<$ http://europa.eu/rapid/press-release_MEMO-13-833_en.htm> accessed 14 July 2014.

80 See (n 78) 172.
} 
been fully articulated and has largely been eclipsed by the concerns about cripplingy high levels of (youth) unemployment. Job creation, by definition, is not susceptible to EU legislation: no Directive can mandate the creation of several million jobs. The OMC process, and now the European semester and EU2020, may provide a framework in which Member States can work on the reforms they need to meet EU targets, but this provides a low visibility solution, and, on the evidence of the Lisbon strategy 2000 , one with a low success rate as well. ${ }^{81}$

In conclusion, the deregulatory agenda combined with the inability of the EU positively to regulate has created a major challenge for the EU at the very time when the EU needs to demonstrate how it is proposing to (re)engage with its citizens. Yet the EU legislative cupboard is currently almost bare. The relevant Commission department, DG Employment, is busy with its part in the Regulatory Fitness exercise, ${ }^{82}$ but in essence this is a process of running on the spot. With the exception of action in certain specific sectors, such as transport, ${ }^{83} \mathrm{EU}$ employment law is going nowhere very fast.

\section{An Alternative Narrative}

The picture painted so far is pretty bleak. It is a tale of problems, obstruction, and difficulty. But I think there is space for an alternative narrative, a narrative which recognizes the pragmatism of the Commission. ${ }^{84}$ It is also a story of adaptability and experimentation and, ultimately, survival. I want to argue that EU social policy, at least in the employment field, has shown a remarkable degree of resilience.

81 The EU2020 targets include a 75\% employment rate among 20- to 64-year-olds and at least 20 million fewer people in, or at risk of, poverty or social exclusion. While the employment rate was $68.5 \%$ in 2010 , it fell to $68.3 \%$ in 2013 . The number of people in, or at risk of, poverty or social exclusion was 118 million in 2010, but 124 million in 2012 $<$ http://europa.eu/rapid/press-release_SPEECH-14-455_en.htm > accessed 20 July 2014.

82 See eg Commission, Regulatory Fitness and Performance Programme (REFIT): Initial Results of the Mapping of the Acquis, SWD (2013) 401 and for criticism, see Wolfgang Kowalsky, 'REFIT - a Breakthrough towards a Strengthened and more Encompassing Deregulatory Agenda' (2014) 20 Transfer 305.

83 See eg 'the Proposal to extend certain employment directives to seafarers' $\operatorname{COM}(2013) 798$.

${ }^{84}$ Laura Cram, Policy-Making in the European Union: Conceptual Lenses and the Integration Process (Routledge 2005) 159. 


\section{Pragmatism (or Opportunism?)}

The EU's approach to social policy, and that of the Commission in particular, is based on pragmatism, an ability to tack to the prevailing winds and to shape a social policy accordingly. This can be illustrated by looking at two periods of the EU's existence.

First, take the early period. As we have seen, there was next to no substantive social policy in the Treaty of Rome because social policy was largely viewed as a matter of national law. However, within 15 years, the Heads of State had declared that EU social policy was as important as economic policy; in Defrenne (No 2), ${ }^{85}$ the Court of Justice expressed similar sentiments. And the 1970 s witnessed a phase of considerable legislative activity, focussed on three areas: gender equality, health and safety, and restructuring. Directives on gender equality were adopted, loosely justified by the fact that 'the principle that men and women should receive equal pay contained in Article [157] of the Treaty is an integral part of the establishment and functioning of the common market' ${ }^{86}$ This was a smart move by the EU; the Directives gave key rights, primarily to women, and it made the EU look progressive. Focussing on health and safety was also a sensible policy choice: given the human and economic cost of injuries and death at work, it was a policy area which commanded considerable support. The restructuring directives were pegged to the need for the EU to address the social consequences of the creation of the (then) common market: firms would close and jobs would be lost. EU social policy was not intended to interfere with this process; rather it was intended to smooth out some of the bumps for those most affected, namely the employees. Thus, the EU was giving the common market a human face while at the same time trying to stop unfair competition between states.

Second, take the period of the late 1990s and onwards. The momentum for adoption of EU employment legislation in the Delors' period (late 1980s, early 1990s) had slowed significantly and, as we have seen, concern was increasingly focussed on job creation. This change was first heralded by the early launch of the Luxembourg process in 1997 which later mutated into the Lisbon Strategy 2000, the European semester and the EU2020. While this was inevitably a response to the economic situation of the time, it was an implicit recognition that the EU legislative framework had pretty much run its course, at least for the time being.

86 Preamble to Dir 75/117. 
Legislation adopted in this period was targeted towards these broader objectives of job creation. Take for example the two equality Directives, Directives 2000/78 ${ }^{87}$ and Directive 2000/43. ${ }^{88}$ Yes, they fitted into the equality discourse, but were also harnessed to the emerging EES and, even possibly, to the capabilities agenda. For example, the Preamble to Directive 2000/78 says that employment is seen as the key to citizenship, 'guaranteeing equal opportunities for all' and enabling the 'full participation of citizens in economic, cultural and social life and realizing their potential'. 89

These examples show how the EU has been either pragmatic (to its supporters), or opportunistic (to its critics), in crafting an EU-level social policy. The result has been a patchwork of measures which have supplemented and complemented, but never replaced, national social policy. In some states, such as the UK, these rights have proved a valuable addition to national employment protection in a way that International Labour Organisation (ILO) Conventions, however important on the international stage, have not.

\section{Adaptability and Experimentation}

The second characteristic of EU social policy is its adaptability: to the diversity of national industrial relations traditions and to the changing political winds. This has manifested itself in the Commission's willingness to experiment with different modes of regulation.

Contrary to popular perception, EU social policy has never been of the 'command and control' type. So, even the earliest Directives adopted by the EU in the 1970s laid down only minimum standards, before this became the vogue elsewhere. ${ }^{90}$ Thus, the EU social directives did provide some scope for regulatory competition between Member States but only above the floor of rights. It was hoped this competition might precipitate a race to the top.

87 Dir 2000/78 establishing a general framework for equal treatment in employment and occupation (OJ [2000] L303/16).

${ }_{88}$ OJ [2000] L180/22.

89 Dir 2000/78 establishing a general framework for equal treatment in employment and occupation (OJ [2000] L303/16), ninth preambular paragraph.

${ }_{90}$ Most of the social Directives are minimum harmonization Directives and some Directives also contain a 'non-regression clause': see eg Art 16 of Council Dir 94/33/ EC (OJ [1994] L216/12) '.. as long as the minimum requirements provided for by this Directive are complied with, the implementation of this Directive shall not constitute valid grounds for reducing the general level of protection afforded to young people'. See Steve Peers, 'Non-regression Clauses: The Fig Leaf has Fallen' (2010) 39 ILJ 436. 
EU social policy has also experimented with other innovations. For example, it has made good use of framework directives which lay down general rules, the details of which are left to be fleshed out by the Member States/social partners (see eg Parental Leave Directive 96/34, ${ }^{91}$ (repealed and replaced by Directive 2010/18/EU ${ }^{92}$ ), and the Fixed-term Work Directive $99 / 70,{ }^{93}$ both of which were the result of agreements negotiated by the social partners), and controlled derogations, such as those found in the Working Time Directive 2003/88 ${ }^{94}$ which allowed variation of statutory standards by collective agreement. Sometimes, the carrot to negotiate came with a stick attached. So, for example, the European Works Council Directive $94 / 45^{95}$ (now Directive 2009/38 96 ) encouraged workers and their employers to reach an agreement on what form worker participation should take in their workplace. Failure to reach an agreement meant that the stricter subsidiary requirements found in the Annex would apply. This became the model for the adoption of a number of other Directives, notably the Directives on national-level information and consultation, Directive 2002/14, ${ }^{97}$ and Directive 2003/72 on worker participation in the European Company. ${ }^{98}$

This body of EU labour legislation was described by Deakin and Rogowski as 'reflexive': ${ }^{99}$ reflexive in its formation (direct input from self-regulatory bodies), in its structure (the use of defaults and derogations), and in its implementation (stimulation of self-regulation at national, industry and firm level). This technique, with law used as a steering mechanism, spilled over into the development of the OMC based on guidelines, benchmarking, and peer review ${ }^{100}$ which now characterizes the European semester.

While the creation of EU employment laws has protected workers from some of the rigours of the market, the EU single market rules,

\footnotetext{
1 OJ 1996 L145/9.

OJ 2010 L68/13.

OJ 1999 L244/64.

OJ 2000 L195/41.

OJ 1994 L254/64.

OJ $2009 \mathrm{~L} 122 / 28$.

OJ [2002] L80/29.

OJ [2003] L207/25.
}

99 Simon Deakin and Ralf Rogowski, 'Reflexive Law, Capabilities and the Future of Social Europe' in Ralf Rogowski, Robert Salais and Noel Whiteside (eds), Transforming European Employment Policy: Labour Market Transitions and the Promotion of Capability (Edward Elgar 2011) 235.

100 Simon Deakin and Olivier De Schutter (eds), Social Rights and Market Forces: Is the Open Coordination of Employment and Social Policies the Future of Social Europe? (Bruylant 2005). 
notably the four freedoms and the competition provisions, have threatened to undermine national employment protection, as the decisions in Viking and Laval have demonstrated. Here again the EU legislature has had some success in trying to protect national law. The Posted Workers Directive $96 / 71^{101}$ was an early example. It identified which rights workers would enjoy when posted to a host state in the context of freedom to provide services. It has now been supplemented by the Enforcement Directive. ${ }^{102}$ Although many thought the protection offered to posted workers by Directive 96/71 to be inadequate (posted workers did not enjoy equal treatment with home state workers), the fact is that posted workers did enjoy some protection under host state law, even though they were being posted in the context of Article 56 TFEU (and therefore should have received, in principle, only the protection of home state law).

Subsequently, the Services Directive 2006/123, ${ }^{103}$ introduced to (de)regulate the services market, contained express provisions to protect national employment legislation. Article 1(6) provides that the Directive 'does not affect' national labour law or social security legislation, while Article 1(7) contains the so-called 'Monti' clause:

This Directive does not affect the exercise of fundamental rights as recognised in the Member States and by [Union] law. Nor does it affect the right to negotiate, conclude and enforce collective agreements and to take industrial action in accordance with national law and practices which respect [Union] law. ${ }^{104}$

A more creative and imaginative marriage between social policy and the single market can be found in the revised public procurement directives. These Directives contain significantly more robust social provisions than their 2004 predecessors. ${ }^{105}$ In particular, Article 18(2) of the General Directive 2014/24 provides:

\footnotetext{
101 OJ 1997 L18/6.

102 <http://europa.eu/rapid/press-release_IP-14-542_en.htm> accessed 14 Aug 2014. See also Dir 2014/54/EU on measure facilitating the exercise of rights conferred on workers in the context of freedom of movement of workers (OJ 2014 L128/8).

103 OJ 2006 L376/36.

104 A similar Monti clause has been inserted into one of the 'six pack' measures, the Macro-economic Surveillance Regulation 1176/2011, Art 1(3) (OJ [2011] L306/25). See also Recital 25 which adds 'When the Council and the Commission apply this Regulation, they should fully respect the role of national parliaments and social partners and respect differences in national systems, such as the systems for wage formation.'

105 <http://www.europarl.europa.eu/news/en/news-room/content/20140110IPR323 86/html/New-EU-procurement-rules-to-ensure-better-quality-and-value-for-money > accessed 10 July 2014.
} 
Member States shall take appropriate measures to ensure that in the performance of public contracts economic operators comply with applicable obligations in the fields of environmental, social and labour law established by Union law, national law, collective agreements or by the international environmental, social and labour law provisions listed in Annex X.

Annex X refers to the major ILO Conventions, including No 87 on Freedom of Association and the Protection of the Right to Organize, No 98 on the Right to Organize and Collective Bargaining, and No 29 on Forced Labour. In practical terms, Directive 2014/24 may produce more significant, long-term benefits for social policy than a new specific social policy directive whose content has been so watered down to accommodate the interests of 28 States as to be almost meaningless.

Directive 2014/24 provides an interesting example of using the power of the procurement market to ensure the enforcement of both national, EU and ILO rules while at the same time allowing states to experiment with different approaches as to how to promote social interests. Enforcement may provide a more promising space for EU action going forward. We return to this point below.

The discussion so far has focussed on the EU's ability to adapt to the prevailing winds and to experiment. Some of its experiments have been more successful than others: in some states, like the UK, the Information and Consultation Directive 2002/14 has produced scarcely a ripple, despite its broad framework nature. This can be explained in part by the hostile environment into which it had to be implemented. By contrast, the atypical work directives, particularly the Fixed-term work Directive 99/70, have had profound effects on most of the national systems.

\section{Survival}

Despite the sense of crisis surrounding EU social policy, the fact is that a fairly extensive body of EU regulation remains. Sure, it is not perfect, and it is imperfectly implemented and enforced in the Member States but it is there, and, by and large, it is beneficial. It is now hard to think of a time when, for example, discrimination on the grounds of race, disability, or sex was not prohibited. ${ }^{106}$ And, outside the field of collective rights, the Court has still managed to deliver judgments which have raised or at least

106 See also Marie Ange Moreau, 'Labour Relations and the concept of social justice in the European Union' in Hans Micklitz (ed), The Many Concepts of Social Justice in European Private Law (Edward Elgar 2011) 317: 'the European social model carries, in all its complexity, a power of recovery'. 
reinforced the social floor. In Lock, ${ }^{107}$ the Court insisted that commission payments, paid in addition to basic salary, could not be excluded from the calculation of a worker's pay when taking paid annual leave. In Bollacke, ${ }^{108}$ the Court ruled that where a worker died with periods of leave outstanding his beneficiary (his wife) was entitled to the equivalent of the pay in lieu.

But even if the EU is not rolling back its own social legislation, critics would say that the combined effect of the troika intervention in the bail-out countries and the CSRs are undermining key pillars of national social legislation. Let us consider the troika intervention first. As we have seen, the ETUC has strongly condemned the Troika's intervention in the bailout countries and documented the social problems that have resulted. ${ }^{109}$ Further, in a report commissioned by the ETUC, its expert found that the austerity measures adopted in response to troika recommendations were incompatible with human rights. ${ }^{110}$ This is not the place to engage in detail with each of the allegations. However, two points should be borne in mind. First, there was no troika recommendation to cut labour standards below the EU minimum. EU social policy did provide a floor of rights, although in the bail-out countries the floor increasingly looked like a ceiling. I do accept that the dramatic reforms to Greek labour law show what can be achieved even in the presence of EU social policy but this raises the question about the scope of social policy going forward, a point we return to below.

Second, at the height of the crisis, a number of socialist/left of centre governments were thrown out by voters and replaced by centre right governments either after the terms of the bail-out was agreed (Portugal) or just before (Spain). There was clearly a feeling in a number of Member States that there was a time for change and reform. Two of the bail-out countries (Portugal and Greece), together with Spain which for these purposes almost counts as a bail-out country, were under dictatorships until the mid 1970s. Some of their labour laws date from that time or have their origins in that period and were highly protective. They still apply in the very different circumstances of today. In the normal course of events, major change is done in a democratic way: discussion papers, public deliberation,

\footnotetext{
107 Case C-539/12 Z. JR Lock v British Gas Trading Limited [2014] ECR I-000.

108 Case C-118/13 Gülay Bollacke v K+ K Klaas \& Kock BV \& Co KG [2014] ECR I-000.

$109<$ http://www.etuc.org/IMG/pdf/THE_FUNCTIONING_OF_THE_TROIKA_ finaledit2afterveronika.pdf $>$ accessed 10 July 2014.

110 'Austerity is Illegal: European trade unions demand a change of policy- Troika acts against EU law and human rights, according to senior lawyer' <http://www.etuc.org/a/ $11794>$ accessed 10 July 2014.
} 
debates in Parliament. But where the democratic system faces deep-seated problems, as it does in Spain, the usual transmission mechanisms do not work and it may take an outside body to come in to provide some impetus to the reform process.

As a result of intervention by the Commission through the CSRs, and pressure from the Organisation for Economic Cooperation and Development (OECD) and the International Monetary Fund (IMF), there was a major labour law reform in Spain in 2012. This included reducing the levels of compensation for dismissal and increasing the possibility of plant-level collective bargaining. The unspoken aim of the reforms was to reduce salaries with a view to improving external competitiveness in order to facilitate export-led growth. And there are signs that this policy has worked and that 'a mild recuperation in the jobs market is taking place, helped by labour market reform in 2012 and the persistent drop in wages'. ${ }^{111}$ Certainly exports are increasing significantly, currently growing at a rate of about $8 \% .{ }^{112}$ Much depends on your perspective as to whether the price of these reforms, in particular continued precarity, are worth it, but many mainstream commentators would accept that something had to be done to unblock labour law in these states.

\section{What is the Future of EU Social Policy?}

\section{Introduction}

While I have described the EU's approach to social policy as a story of pragmatism, adaptability and survival, others have described it as merely 'muddling through'. ${ }^{113}$ Whatever the epithet, I think the current ESM was the best that could be hoped for in the circumstances. And it does

\footnotetext{
111 T Buck, 'Recovery accelerates in recession-hit Spain' FT (14 January 2014). The finance minister is quoted as saying: 'Our projection is that the labour market reform has clearly reduced the threshold at which we start to create jobs. Traditionally, the Spanish economy had to grow by more than 2 per cent to start to create jobs in net terms. Now we think that a growth rate of about 1 per cent [year-on-year] is enough to start creating jobs': <http://www.ft.com/intl/cms/s/0/65c0e9fe-1556-11e3-b519-00144feabdc0.

html\#axzz2rnYyCgVP > accessed 10 July 2014. More generally, see Wolfgang Schäuble, 'Ignore the Doomsayers: Europe is being Fixed' Financial Times (London, 16 September 2013). cf the position in the UK where exports are not booming: Sarah O'Connor, 'Oneway traffic' Financial Times (London, 22 August 2013).

112 Tobias Buck, 'Spain reaps benefit of austerity measures, says economy minister' $<$ http://www.ft.com/intl/cms/s/0/65c0e9fe-1556-11e3-b519-00144feabdc0.html\#axzz $2 \mathrm{rnYyCgVP}>$ accessed 10 July 2014. See also $<$ http://focus.ie.edu/why-spain-becomingexport-powerhouse $>$ accessed 10 July 2014.

113 Vandenbroucke and Vanhercke (n 39) 16, 63.
} 
suggest that the same spirit of pragmatism will ensure that there is a future for the continued development of the ESM.

But what might it be? Vandenbroucke and Vanhercke have an ambitious vision: ${ }^{114}$

Europe needs a Social Union that can support national welfare states on a systemic level in key functions such as macroeconomic stabilisation, and also guide the development of national welfare states on the basis of general social standards and objectives. That would leave decisions on the ways and means of social policy to the Member States. In other words, European countries would cooperate in a union with an explicit social purpose: hence the expression 'European Social Union'. ${ }^{115}$

Deakin and Koukiadaki envisage something similar. They talk of 'solidaristic integration'. This, they say, implies the deepening of EU integration on the basis of new forms of solidarity, involving an expansion of the European budget 'to deliver fiscal transfers from the core to the periphery and replacement of the model of competition among national legal systems by the harmonisation of the Member States' social and fiscal laws'. ${ }^{116}$

For the eurozone states, this may indeed be the best and necessary solution. Vandenbroucke and Vanhercke recognize the enormous difficulties facing their proposals, especially at a time of growing eurosceptism and a desire that Brussels has fewer, not more, powers. This story is even more acute in the non-eurozone states, especially the UK. So I shall focus on an agenda which might hold some appeal to an EU of 28, or at least a combination of both Eurozone and non-Eurozone states, and this inevitably focuses on the narrower domain of employment law.

And any discussion must be tempered by political reality-and pragmatism for this is what the Commission will continue to have to demonstrate. Calls for the EU to adopt a comprehensive social policy, exceeding the level of protection provided by the best of the Member States, might provide a magnificent floor of rights to protect, for example, Greek workers from further deregulation, but is politically unfeasible, ${ }^{117}$

114 See (n 39) 16.

115 See also Colin Crouch, 'Why We Need More Social Europe' Social Europe Journal (4 July 2014) <http://www.social-europe.eu/2014/07/need-social-europe/> accessed 15 July 2014.

116 See (n 70) 187. See also Commissioner Andor, 'Social Dimension of the Economic and Monetary Union: What Lessons to Draw from the European Elections' (13 June 2014) <http://europa.eu/rapid/press-release_SPEECH-14-455_en.htm> accessed 15 July 2014.

117 And potentially legally unfeasible: see the Lisbon judgment of the German Bundesverfassungsgericht (2 BvE 2/08, 2 BvE 5/08, 2 BvR 1010/08, 2 BvR 1022/08, 2 
especially in states such as the UK which is eyeing up social policy as a key area for the repatriation of powers. So the proposals that follow are deliberately less ambitious. I shall consider four possibilities:

- sit tight and do nothing

- a European social compact

- structured reform of labour law by states in a crisis situation

- more modest proposals

The first possibility essentially describes the approach the Commission is taking at the moment (with the notable exception of public procurement): batten down the hatches and hope for fairer weather which might provide the opportunity for more creativity. This possibility is a potentially dangerous strategy because it suggests that social policy is there for fair days and holidays and is not an integral part of the EU's project. ${ }^{118} \mathrm{I}$ would like to see some more ambition. I shall therefore focus on the three other possibilities and, in so doing will also examine whether it is necessary that all measures apply to all states.

\section{A European Social Compact}

\section{The compact}

The most radical of the proposals would be the creation of a European Social Compact to match the Fiscal Compact. This would contain a strong statement of the value and importance of social policy in the EU and would help to address the problem identified above of the prioritizing of economic over social interests. This would send a stronger message to the legislature and to the courts of the role and function of social policy, a message that the phrase 'social market economy' has failed to send with significant force.

BvR 1259/08 and 2 BvR 182/09: European unification on the basis of a union of sovereign states under the Treaties may, however, not be realized in such a way that the Member States do not retain sufficient room for the political formation of the economic, cultural and social circumstances of life. This applies in particular to areas which shape the citizens' circumstances of life, in particular the private space of their own responsibility and of political and social security.

118 cf Sonja Bekker and Saskia Klosse, 'EU Governance of Economic and Social Policies: Chances and Challenges for Social Europe’ (2013) 6 Eur J Soc L 103. 
The ETUC has long been pressing for some form of social progress protocol. It suggests the following wording: ${ }^{19}$

Nothing in the Treaties, and in particular neither economic freedoms nor competition rules shall have priority over fundamental social rights and social progress as defined in Article 2. In case of conflict fundamental social rights shall take precedence. ${ }^{120}$

It is unlikely that any of the Member States would be able to sign up to such an exclusive priority of the social interests over the economic; their unhappiness over the more nuanced Monti II statement of balance between economic and social rights bears testimony to this. However, some of the ETUC's other suggestions might carry more weight and could be included in a Social Compact. For example, it identifies the following functions of EU social policy, in particular the fact that the Union:

- improves the living and working conditions of its population as well as any other social condition,

- ensures the effective exercise of the fundamental social rights and principles, and in particular the right to negotiate, conclude, and enforce collective agreements and to take collective action,

- protects workers by recognizing the right of workers and trade unions to strive for the protection of existing standards as well as for the improvement of the living and working conditions of workers in the Union going beyond existing (minimum) standards, in particular to fight unfair competition on wages and working conditions, and to demand equal treatment of workers regardless of nationality or any other ground,

- ensures that improvements are being maintained, and avoids any regression in respect of its already existing secondary legislation.

In the light of the experience in the bail-out countries, the last clause on non-regression from pre-existing EU standards is particularly important. The ETUC continues that:

The Member States, and/or the Social Partners, are not prevented from maintaining or introducing more stringent protective measures compatible

$119<$ http://www.etuc.org/a/5175> accessed 14 July 2014.

120 See also Julian Nida-Rümelin and others, 'We Need a Europe that is Truly Social and Democratic' Social Europe Occasional Paper (10-11 November 2013). 
with the Treaties; when implementing Union secondary legislation, avoid any regression in respect of their national law, without prejudice to the right of Member States to develop, in the light of changing circumstances, different legislative, regulatory or contractual provisions that respect Union law and the aim of social progress.

The non-regression clause envisaged here is of a different type: it stops Member States from using EU law as an excuse to lower pre-existing national standards but only when implementing EU law. It does notnor probably should it - go so far as to propose preventing states from cutting labour standards generally when outside the scope of EU law (but possibly required as a condition of an EU bail-out).

I would like to propose other possible matters for inclusion in any Social Compact. For example, I would like to see express reference being made to other social rights documents, including the European Social Charter of 1961, to create a greater opening of the EU to other international instruments. I would also suggest the need for a clause which explicitly requires the BEPG to take account of social matters.

More radically, I would also like to see the mandate of the ECB to be extended, like that of the Federal Reserve in the US and other central banks, to promoting economic growth, as well as high levels of employment and social cohesion, and not just the maintenance of price stability, as specified in Article 127 TFEU. Although the orthodox view was that by ensuring price stability through monetary policy, growth would follow, and that would create the conditions of full employment, this has clearly not been the case. Proponents of the ECB's position would argue that the reason why there is not full employment is due to rigidities in the labour market - and those rigidities are caused by unnecessarily restrictive labour law rules and collective bargaining. However, for all the neo-liberals who make this case, there are significant voices which contest the link between the reform to national employment protection legislation and employment creation. ${ }^{121}$ Even

121 See eg Klaus Armingeon and Lucio Baccaro, 'Political Economy of the Sovereign Debt Crisis: The Limits of Internal Devaluation' (2012) 41 ILJ 254 and 'Do Labor Market Liberalization Reforms Pay off?' < http://www.ipw.unibe.ch/unibe/wiso/ipw/content/ e2425/e2426/e93619/e95082/files101682/ArmingeonandBaccaro-DoLaborMarketLibe ralizationReformsPay-Off_ger.pdf $>$ accessed 14 July 2014; Simon Deakin, Jonas Malmberg, and Prabirjit Sarkar, 'Do Labour Laws Increase Equality at the Expense of Higher Unemployment? The Experience of Six OECD Countries, 1970-2010', CBR Working Paper Series WP442, Centre for Business Research, Cambridge: 'We find that worker-protective labour laws in general have no consistent relationship to unemployment but are positively correlated with equality.' 
the OECD has toned down its rhetoric in that regard from the high point of neo-liberalism in the $1994 .^{122}$

Of course, those like Vandenbroucke and Vanhercke, and now JeanClaude Junker (see below), might see the introduction of any such social compact as an opportunity for introducing eurozone unemployment insurance as a way of combating asymmetric shocks. Following Deakin and Wilkinson, this might have the effect of precipitating an increase in employment protection legislation so that employers find it harder to get rid of people and thus keep them from being a burden on the welfare state.

\section{The legal form of the Compact}

Assuming an agreement can be reached on the content of a Social Compact, what legal form might it take? The most obvious could be a Treaty amendment-but with all the difficulties this would entail. Another option would be a Decision of the EU Heads of State and Government, meeting within the European Council. As Peers notes, ${ }^{123}$ such Decisions have been adopted in the past, as regards Denmark ${ }^{124}$ and Ireland, ${ }^{125}$ in order to address Denmark's difficulties ratifying the Maastricht Treaty and Ireland's with the Treaty of Lisbon. In the latter case, the Decision was 'legally binding'. It did not constitute a Treaty amendment but its content was to be set out in a Protocol which would be attached to the Treaties in the future. The Protocol was subsequently signed as promised. ${ }^{126}$

Ideally any Social Compact would apply to all 28 states. However, the current political climate makes this unlikely (the UK would certainly vote against, as might a number of other Member States worried about the implications of a Treaty amendment on their own national systems). This inevitably means looking at some sort of free standing Treaty, like the Fiscal Compact/Treaty on Stability, Coordination and Governance (TSCG), which could be signed up to by interested Member States and have force under international law. Another model for flexibility would be to follow the pattern of the Euro Plus Pact (EPP), agreed by interested Member States. It is not legally binding but it is taken into account in the

\footnotetext{
$122<$ http://www.oecd.org/employment/emp/1941679.pdf >; Colin Crouch, 'Introduction: Labour Markets and Social Policy after the Crisis' (2014) 20 Transfer 7, 10.

123 EU Law Analysis, 28 June 2014.

124 OJ [1992] C348/1.

125 <http://www.consilium.europa.eu/uedocs/cms_data/docs/pressdata/en/ec/108622. pdf $>$ accessed 14 July 2014.

126 OJ [2013] L60/129 and 131.
} 
various soft-law processes, rather in the way of the Stability and Growth Pact Resolution of $1997 .^{127}$

Both proposals would give the social dimension a certain visibility; the disadvantage is that any Social Compact risks assuming some sort of second class status, like the European Social Charter, alongside its bigger European Convention brother. It also risks creating further fragmentation within the EU, and, in the case of a Social Compact Treaty, suggests that international treaties are increasingly the normal way to do business. More problematic still, any such text might fall outside the umbrella of the EU values and objectives, including the social market economy, unless the Member States commit themselves to applying principles of EU law. ${ }^{128}$ For these reasons, some commentators reject any idea of a European Social Union as a 'parallel and separate social pillar to be added to the existing pillars'. They would prefer the social dimension to be 'mainstreamed into all EU initiatives because social policies are very often affected by policies pursued in other areas'. ${ }^{129}$ This may include a requirement to establish more rigorous social impact assessments, ${ }^{130}$ especially in the context of macroeconomic adjustment programmes and bail-outs. There is some hope that this measure will have traction. In his manifesto, Jean-Claude Junker, the new Commission president, says: ${ }^{131}$

We should also re-balance the way in which we grant conditional stability support to Eurozone countries in financial difficulties. I propose that in the future, any support and reform programme goes not only through a fiscal sustainability assessment; but at the same time through a social impact assessment. The social effects of structural reforms need to be discussed in public. ...

He adds: 'It is not compatible with the social market economy that during a crisis, ship-owners and speculators become even richer, while pensioners can no longer support themselves.' He also seems sympathetic

\footnotetext{
$127<$ http://europa.eu/legislation_summaries/economic_and_monetary_affairs/stabilit y_and_growth_pact/l25021_en.htm $>$ accessed 15 July 2014 .

${ }_{1 \overline{2} 8}$ Cf Art 2(1) TSCG: "This Treaty shall be applied and interpreted by the Contracting Parties in conformity with the Treaties on which the European Union is founded, in particular Article 4(3) of the Treaty on European Union, and with European Union law, including procedural law whenever the adoption of secondary legislation is required.' 129 Vandenbroucke and Vanhercke (n 39) 22.

130 Commission Guidance already exists on 'Assessing Social Impacts within the Commission Impact Assessment System' < http://ec.europa.eu/smart-regulation/im pact/key_docs/docs/guidance_for_assessing_social_impacts.pdf > accessed 10 July 2014.

$131<$ http://juncker.epp.eu/my-priorities> accessed 10 July 2014.
} 
to some of the ideas raised by Vandenbroucke and others: ${ }^{132}$ 'a targeted fiscal capacity at Eurozone level could be developed to work as a shockabsorber, if needed'.

\section{Structured Reforms in Times of Crisis}

The reforms to national labour law rules, introduced as a condition of financial support in Greece, have already been condemned by the European Committee on Social Rights as breaching the European Social Charter 1961. ${ }^{133}$ The reforms have certainly reached deep into the national systems. The ETUC has produced a number of examples of how the troika policies have trampled over existing social partner agreements, precipitated cuts or freezing of the minimum wage and cutting compensation on dismissal below the European average ${ }^{134}$ notably all areas in which there is no EU-level floor of rights. The European Parliament's investigation has shed some more light on the work of the troika. ${ }^{135}$

It was certainly the case that with Greece the sense of crisis was palpable and there was a perception that action had to be taken very quickly to save Greece and the euro. ${ }^{136}$ Mistakes were made ${ }^{137}$ and the Greek people

\footnotetext{
132 See n 39.

133 See eg Federation of Employed Pensioners of Greece (IKA-ETAM) v Greece, Complaint No 76/2012; Panhellenic Federation of Public Service Pensioners (POPS) v Greece, Complaint No 77/2012; Pensioners' Union of the Athens-Piraeus Electric Railways (ISAP) $v$ Greece, Complaint No 78/2012; Panhellenic Federation of Pensioners of the Public Electricity Corporation (POS-DEI) v Greece, Complaint No 79/2012; Pensioner's Union of the Agricultural Bank of Greece (ATE) v Greece, Complaint No 80/2012. See also the resolutions adopted by the Committee of Ministers: CM/ResChS(2014)7, CM/ ResChS(2014)8, CM/ResChS(2014)9, CM/ResChS(2014)10 and CM/ ResChS(2014)11.

$134<$ http://www.etuc.org/IMG/pdf/THE_FUNCTIONING_OF_THE_TROIKA_ finaledit2afterveronika.pdf $>$ accessed 10 July 2014.

135 P7_TA-PROV(2014)0240 Employment and social aspects of the role and operations of the Troika (A7-0135/2014 - Rapporteur: Alejandro Cercas) European Parliament resolution of 13 March 2014 on Employment and social aspects of the role and operations of the Troika (ECB, Commission and IMF) with regard to euro area programme countries (2014/2007(INI)).

136 For the first writing of the history, see Peter Spiegel, 'How the Euro was Saved' Financial Times (London, 12, 15 and 16 May 2014).

137 'IMF Admits Mistakes on Greece Bailout' < http://www.bbc.co.uk/news/business22791248> 5 June 2013; Valentina Pop, 'Troika officials admit errors, as criticism mounts' <http://euobserer.com/economic/121993> 6 November 2013; <http://gree ce.greekreporter.com/2014/01/30/greek-finmin-troika-made-many-mistakes/ (Greece); $<$ http://www.rte.ie/news/2013/0612/456279-finance-min-admits-mistakes-made-withtroika/ > (Ireland); see also the speech by EU Social Affairs Commissioner Andor <http:// europa.eu/rapid/press-release_SPEECH-14-455_en.htm> accessed 14 July 2014.
} 
continue to pay the price for those mistakes. But the EU now has experience of four bail-out programmes (Greece, Portugal, Ireland, and Cyprus) and four financial assistance programmes (Hungary, Latvia, Romania, and Spain). With the pressure of the impending catastrophic implosion of the euro being removed, now would be a good time for the EU to take stock and see the lessons learned. On a micro-level, was the $\mathrm{EU} /$ troika correct in placing so much emphasis on the reforms to national labour law? On a macro-level, there is a need for serious discussion of whether austerity-based reforms are really the appropriate medicine for countries in difficulty, ${ }^{138}$ especially when prescribed to all Member States at the same time (Keynes' paradox of thrift). ${ }^{139}$

At a more procedural level, a protocol should be drawn up which could be used in the event of a future bail-out situation. The close monitoring of the EU Member States through the European semester programme means that crises like those in Greece should not develop with such unexpected rapidity. So there would be time for a more consultative process. This could require, for example, that the Commissioner of DG Empl serve on the troika or any EU-specific body charged with overseeing financial support and imposing conditionality, as well as MEPs, for example from the employment and social affairs committee, who can help screen proposals for compliance with the EU social acquis and the Charter. Representatives from the ILO might have observer status. More radical would be a requirement for the Court of Justice to verify that the structural adjustment programme is compatible with the EU social acquis, using a similar process to the advisory opinion procedure, combined with the rapidity of the procédure préalable d'urgence (PPU). ${ }^{140}$ Furthermore, the Protocol should prescribe that social partners at EU and national level need to be more actively involved; where an agreement has

138 According to the ILO's Social Protection report, n 16, 137 in Ireland, Greece, Portugal and Cyprus, where some of the boldest structural reforms have taken place as part of the terms agreed under the different economic adjustment programmes adopted by these countries since 2008, disposable household incomes have declined in consequence, as a result of high unemployment, lower wages and social protection expenditure cuts, and this in turn has led to lower consumption. At pages 137-138, it adds the reforms have 'disproportionately emphasized the fiscal objective of balancing public budgets without due consideration to the objective of adequate benefits to all people'. It continues that such disequilibrium constitutes a significant danger for 'social justice, and contributes to the erosion of the European social model'.

139 For a forceful critique of austerity policies, see Mark Blyth, Austerity: A History of an Idea (OUP 2013).

140 Catherine Barnard, 'The PPU: Is it Worth the Candle? An Early Assessment' (2009) 34 ELR 281. A new procedure might require a Treaty amendment unless it is thought that a creative reading of Article 273 TFEU could deliver this. 
been reached by the national social partners, this should be respected. The troika should also be accountable to the European Parliament.

The drawing up of such a protocol would have the advantage of making any bail-out process more transparent. The involvement of a much wider range of actors would help to provide greater legitimacy for steps being taken in the name of EU citizens. There may well be public interest in the need for reforms to the labour law systems. Doing so in a more structured, inclusive way may satisfy the Court's demands for proportionality in the case of any rights infringed.

\section{More Modest Proposals}

\section{Specialization}

I fully accept that a Social Compact is a long shot. A bailout protocol of the kind outlined above might be appealing but it does not confer any meaningful rights which shape an EU social policy going forward. So what could the EU be doing to boost the social dimension in the medium term and thus help to address concerns about the EU's legitimacy while at the same time offering some EU added value? I would suggest the EU go back to its roots and, as it did in the 1970s, specialize. There are three areas which could be singled out as needing the EU's attention, where EU level activity might be justified given the transnational dimension, and where action has a direct connection with the European Semester: ageing population, enforcement, and addressing the consequences of privatization. We shall look at these in turn.

The first potential area of specialization concerns the employment and pensions implications of an ageing population. This is already flagged up in the EPP:

'Reforms necessary to ensure the sustainability and adequacy of pensions and social benefits could include:

- aligning the pension system to the national demographic situation, for example by aligning the effective retirement age with life expectancy or by increasing participation rates;

- limiting early retirement schemes and using targeted incentives to employ older workers (notably in the age tranche above 55).

The justification for EU involvement here relates to the key issue of sustainability of public finances which, as the Eurozone crisis has shown, is a matter of common interest. The EU has long had expertise in the discrimination area, starting with sex and then in respect of other 
protected characteristics. Addressing age discrimination/extending working life initiatives/flexible working fits in with this specialization while dovetailing with the EU's social cohesion agenda. On a related issue, developing family-friendly policies — which would include elder care as well as child care-would also fit within this theme. ${ }^{141}$ The reform of the Parental Leave Directive serves only to highlight other lacuna in EU provision such as the absence of provisions on the right to request reduced hours of working. There may be room for EU intervention here.

Second, there is a growing body of evidence that migrant workers are being mistreated by some employers in certain sectors, particularly meat processing, ${ }^{142}$ as are domestic workers. ${ }^{143}$ If these workers cannot, for practical reasons, enforce their rights, there is a role for the EU to consider intervening to require effective remedies. The new Directive on free movement of workers is a step in the right direction. ${ }^{144}$ But there is evidence that migrant workers do not enforce their rights through tribunals. ${ }^{145}$ This requires more pro-active enforcement. Is there a role for greater coordination at EU level of, for example, labour inspectors? Or even, more radically, some sort of Europol for labour inspections?

If the EU was to devote its attention to the position of (vulnerable) migrant workers, other issues arise for these workers (as well as for nationals). In particular, what sort of contracts do they have? In recent years, there has been a proliferation of new types of contracting, including zerohour contracts (an employment relationship where the employer is not obliged to provide the worker with work), internship (voluntary work experience where the intern does work which may be equivalent to a paid member of staff), crowd employment (virtual platforms matching buyers and sellers of services), labour pooling (an individual worker is jointly hired by a group of employers and works on a rotating basis in the

${ }^{141}$ See eg in the UK The Flexible Working Regulations 2014 (SI 2014/1398), which gives to all employees with 6 months service the right to request flexible working.

$942<$ http://www.equalityhumanrights.com/media-centre/2010/march/inquiry-uncov ers-mistreatment-and-exploitation-of-migrant-and-agency-workers/> accessed 10 July 2014; Migration Advisory Commitee, 'Migrants in Low-Skilled Work' < https://www. gov.uk/government/publications/migrants-in-low-skilled-work> accessed 15 July 2014. 943 EU Council Decision 2014/51/EU authorizes Member States to ratify, in the interests of the EU, the Convention concerning decent work for domestic workers, 2011, of the International Labour Organisation (Convention No 189) (OJ 2014 L32/32).

${ }_{144}$ Dir 2014/54/EU on measure facilitating the exercise of rights conferred on workers in the context of freedom of movement of workers (OJ $2014 \mathrm{~L} 128 / 8$ ). See also the Commission's 7-year strategy on health and safety <http://ec.europa.eu/social/main. jsp?langId=en\&catId=82\&newsId=2053\&furtherNews=yes $>$ accessed 15 July 2014 .

145 Catherine Barnard, 'Enforcement of Employment Rights by Migrant Workers in the UK: The Case of EU-8 Nationals' in Cathryn Costello and Mark Freedland (eds), Migrants at Work (OUP 2014). 
participating company), and employee sharing (secondment of workers, including the French 'portage salarial'). To what extent do individuals engaged in this kind of work benefit from employment protection legislation traditionally given only to those defined as 'employees'? Should the EU envisage a new type of contract such as Freedland's contract to provide personal service ${ }^{146}$ which would provide a gateway to employment protection?

Of course, these are highly sensitive issues which do not attract much consensus even within the Member States, let alone between them. Could the EU take up the cudgels of where it left off in the Modernisation Green Paper $^{147}$ and raise these issues once again? ${ }^{148}$ The EU has already been involved in discussions concerning the single open-ended contract. This has proved influential in Italy but not (yet) Spain where the proposals are seen as deregulatory and potentially contrary to the Constitution. ${ }^{149}$ But such discussions have opened up the possibility for wider debate. Instead of adopting some sort of harmonization directive, could the EU experiment with, for example, a draft model law which states can opt-into if they choose?

Third, privatization of publicly owned industries and services is clearly an important part of the reform agenda for a number of Member States. What are the employment law implications of this? Does the Transfer of Undertakings Directive 2001/23 need revision to provide meaningful rights to transferees in the event of the transfer and for a significant period thereafter? How does the Directive fit into the public procurement process? Is it time for the transfer rules to be re-examined in the light of the new contexts in which they are being invoked?

\section{Market mechanisms}

Since markets and market thinking are now the order of the day, should labour law capitalize on this? In other words, in the continued spirit of adaptability, should the EU experiment with the use of market mechanisms to incentivise good, socially responsible behaviour? To an extent, the new Public Procurement Directive 2014/24 uses just such a technique: contracting authorities can exclude from participation in a procurement

\footnotetext{
146 M Freedland, The Personal Employment Contract (OUP 2003). See also eg Nicola Countouris, The Changing Law of the Employment Relationship (Ashgate 2007).

147 COM(2006) 708.

148 See further Alain Supiot, Beyond Employment: Changes in Work and the Future of Labour Law in Europe (OUP 2001) ch 1.

149 Giuseppe Casale and Adalberto Perulli, Towards the Single Employment Contract: Comparative Reflections (Hart Publishing 2014).
} 
procedure any economic operator who has violated the labour law (and environmental) obligations referred to in Article 18(2) (considered above). ${ }^{150}$ This creates a significant financial incentive for employers/ economic operators to comply with the law. Economic operators can 'cleanse' themselves and be allowed to tender but again this suggests that they must make good any wrongdoing which may include paying their workers adequate compensation.

I have two other examples of how market mechanisms might be used. The first is transparency. ${ }^{151}$ Firms employing more than, say, 20 people would be obliged to publish on their websites certain key information such as staff turnover; staff sickness levels; how much more, as a factor, is the highest paid worker paid than the lowest worker; and workplace diversity statistics. ${ }^{152}$ Such transparency has a cost but modern technology means that such data should be readily available to employers. And it would enable putative employees to gain insights into potential employers which are not available in the corporate publicity material and so shop around. Potential employees may decide to go to the firm where there is a significant discrepancy in pay in anticipation that they may benefit themselves but they may choose to work for an employer with a better balance. If putative employers discover they are consistently losing talented employees to firms with better records, this might incentivise them to improve their social performance. And if firms discover they are losing out in 'beauty parades' to rival bidders for lucrative contracts both in the public and private sectors, rivals who can show they have better employment practices, that may also incentivise them to reflect on their own practices.

There is already some support for EU measures based on transparency. Proposals are now at a fairly advanced stage on the disclosure by large companies (over 500 employees) of non-financial and diversity information (the corporate social responsibility proposal). The disclosed nonfinancial information will at least cover environmental, social, and employee-related matters, respect for human rights, anti-corruption and bribery matters. It will also require companies to include a description of the policies pursued, their outcomes and the risks related to those matters. In addition, large, listed companies must provide the

150 Art 57(4) of Dir 2014/24.

151 See also Michael Bloomberg and Mary Shapiro, 'Give Investors Access to all the Information they Need' Financial Times (20 May 2014) 11.

152 On the problems with the widening gap between wages at the top and the bottom of a firm, see Richard Sennett, The Culture of the New Capitalism (Yale University Press 2006) 34 . 
information on their policy related to diversity of competences and views of the members of administrative, management and supervisory bodies in their corporate governance statement. ${ }^{193}$

The second example of a market mechanism is incentivization. Can EU law and EU funds be used to encourage, even require, local actors to help the local unemployed find work and stay in it for periods of, say 6 months, one year or more? Similar programmes have enjoyed some success in the UK. Could they be rolled out more widely?

\section{The legal tools}

Adapting the words of Mickelthwait and Wooldridge, ${ }^{154}$ the EU is neither 'a monster nor a saviour but an indispensable part of a decent society that, like most organisations, works best when it focuses on doing a few things well'. I have given some examples of what those few things might be. The question is how the EU might deliver them.

The EU has significant legal competence to act in these fieldswhether under Article 153 TFEU (the principal social policy legal basis), Article 21(2) or Article 25 TFEU (the citizenship provisions), Article 26(3) TFEU (on guidelines and conditions necessary for ensuring balanced progress in all sectors of the internal market), Article 46 TFEU (the legal basis on which Directive 2014/54 on measures facilitating the exercise of free movement of workers was adopted), Article 50(1) TFEU on freedom of establishment (the legal basis on which the directive on diversity information is proposed), the internal market legal bases, Articles 114 and 115 TFEU but, following the Monti II debacle, probably not Article 352 TFEU.

The use of any of these legal bases has (de)merits but what is even more important is the political will to act and that seems to be lacking in a number of Member States. So this raises the question of whether enhanced cooperation should be considered in the social policy field 'to enable and encourage a group of Member States to cooperate inside rather than outside the Union, where it is established that the objectives pursued by that cooperation cannot be achieved by the Union as a

\footnotetext{
$153<$ http://www.eu2013.lt/en/news/pressreleases/member-states-mandate-the-preside ncy-to-negotiate-on-directive-regarding-disclosure-of-non-financial-and-diversity-infor mation > accessed 10 July 2014; Proposal for a Directive amending Council Directives 78/ 660/EEC and 83/349/EEC as regards disclosure of non-financial and diversity information by certain large companies and groups $\operatorname{COM}(2013) 207$.

154 John Mickelthwait and Adrian Wooldridge, 'What Happened to the Idea of a Great Society' Financial Times (23 May 2014) 11.
} 
whole'. ${ }^{155}$ The use of enhanced cooperation is strictly limited by the framework for enhanced cooperation between Member States found in Title IV of the TEU and Title III (Article 20 TEU) of Part Six of the TFEU (Articles 326-334 TFEU). ${ }^{156}$ In particular, enhanced cooperation must involve at least nine Member States and must be authorized by the Council which must give its authorization only as a last resort. ${ }^{157}$ The measure adopted must be aimed at furthering the objectives of the Union, at protecting its interests and at reinforcing its integration process, ${ }^{158}$ and must comply with the Treaties and Union law. ${ }^{159}$ In addition, it must not undermine the internal market or economic, social and territorial cohesion, must not constitute a barrier to, or discrimination in, trade between Member States, and must not distort competition between them. ${ }^{160}$ It must also respect the competences, rights, and obligations of those Member States that do not participate in it. Those Member States, in turn, must not impede its implementation by the participating Member States. ${ }^{161}$ Provided these conditions are satisfied, there seems no good reason why enhanced cooperation cannot be used in the social field. It is far from optimal—but certainly better than nothing. The Unitary Patent case $^{162}$ may suggest, too, that it has the Court's blessing.

\section{Conclusions}

Despite the doomsayers, the EU is still intact after the most tumultuous years of its existence. The European Social Model, too, has been battered by the crisis, but it was already in difficulties before that. Reforms were necessary and it was perhaps this point that Draghi was referring to in his now infamous quote at the opening of this article. ${ }^{163}$ In the last 5 years, economic

155 Opinion of Advocate General Bot in Joined Cases C-274/11 and C-295/11 Spain and Italy $v$ Council EU:C:2013:240, [82].

156 See generally Koen Lenaerts and Piet Van Nuffel, EU Law (2nd edn, Sweet \& Maxwell 2011) para 19-003 and specifically see further G de Baere and C Barnard, 'Towards a European Social Union: Achievements and Possibilities under the Current EU Constitutional Framework' (forthcoming).

157 Art 20(2) TEU.

158 Art 20(1), second subpara, TEU.

159 Art 326, first para, TFEU.

160 Art 326, second para, TFEU.

161 Art 327 TFEU.

162 Joined Cases C-274/11 and C-295/11 Spain and Italy $v$ Council EU:C:2013:240.

163 See also Giddens (n 9) 96, 'As I interpret it, he was not saying that the ESM is dead but implying that it will become so if quite sweeping reforms are not made, at least in many Member States.' 
governance and its reform have predominated, often at the expense of the development of the social dimension. The EES has been accommodatedand largely subsumed by - the European semester. This loss of a separate and distinct identity of the EES has been damaging. ${ }^{164}$ (Part of) the EU is conscious of this and it maybe that the new European Parliament and the new Commission will recognize the need to raise the profile of social policy.

Writers from Polyani onwards have recognized that social change comes from political backlash. The same may be true for the EU. ${ }^{165}$ And the Lisbon Treaty creates some space for a reappraisal of old norms: in particular with its reference to a 'social market economy'. As we have seen, the EU has shown an ability to tack with the wind in social matters and to deliver a (leaky) floor of rights. This has proved valuable and sustainable. The EU's regenerative capacity in the field of social policy needs to be shown again. And there are lots of ideas as to what the EU might do.

164 Christophe Degryse, Maria Jepsen and Philippe Pochet, 'The Euro Crisis and its Impact on National and European Social Policies', ETUI Working Paper, 2013.05, 13.

165 See eg Bo Stråth, 'The Monetary Issue and Economic policy' in Joerges and others, (n 44) 59 arguing that 'social-re-embedding impulses might come from the euro' and the reaction to it. 